\title{
The potential use of Sinelobus stanfordi (Richardson, 1901) (Crustacea, Tanaidacea) as a biological indicator of water quality in a temperate estuary of South America
}

\author{
Eugenia Soledad Ambrosio ${ }^{1,2,3}$, Ana Clara Ferreira ${ }^{1,2,3}$ and Alberto Rodrigues Capítulo ${ }^{1,2,3, *}$ \\ ${ }^{1}$ Instituto de Limnología "R. A. Ringuelet" (ILPLA- CONICET La Plata) Bulevar 120 y 61 S/N, La Plata \\ (1900), Buenos Aires, Argentina. \\ ${ }^{2}$ Facultad de Ciencias Naturales y Museo, UNLP. \\ ${ }^{3}$ Consejo Nacional de Investigaciones Científicas y Técnicas (CONICET), Argentina. \\ * Corresponding author: acapitul@ilpla.edu.ar
}

Received: 20/09/2013

Accepted: 17/03/2014

\begin{abstract}
The potential use of Sinelobus stanfordi (Richardson, 1901) (Crustacea, Tanaidacea) as a biological indicator of water quality in a temperate estuary of South America

Sinelobus stanfordi (Richardson, 1901) is a euryhaline tanaidacean distributed worldwide and recorded in the freshwater zone of the Río de la Plata estuary. Despite the vast bibliography on this species, its sensitivity to pollution has never been assessed. This study was conducted in the coastal freshwater tidal zone of the Río de la Plata estuary, encompassing approximately $170 \mathrm{~km}$ of Argentine shoreline subjected to different types of anthropogenic disturbance. Benthic samples were taken seasonally in triplicate in vegetated zones, along with 19 sampling sites from 2005 to 2010. To explore the main environmental gradients within the study area, a principal component analysis (PCA) was conducted. For the interpretation of the most relevant variables, the axis defined by PCA was followed by a varimax-normalised rotation. The ecological optima and tolerance limits of S. stanfordi were calculated for each environmental variable analysed. The multivariate analysis suggested that most of the variations within the study area could be related to the impact of anthropogenic pollution as well as the natural dynamics of the estuary. The abundance of the species was significantly lower in sites with high levels of nutrients and oxygen demands, exhibiting a negative correlation with soluble reactive phosphorous concentrations and a positive correlation with oxygen levels. Turbidity and conductivity did not represent limiting variables for the distribution of this tanaid. This study constitutes the first approach to assess the effect of anthropogenic disturbance on the populations of this crustacean and contributes to the knowledge of tanaidacean ecology. The low species abundance in the most polluted sites would suggest that $S$. stanfordi could be useful in biomonitoring studies in the Rio de la Plata estuary as well as other temperate estuarine systems.
\end{abstract}

Key words: Tanaidacea, Sinelobus stanfordi, ecology and distribution, anthropogenic disturbance, biomonitoring, Río de la Plata estuary, Argentina.

\section{RESUMEN}

Potencial uso de Sinelobus stanfordi (Richardson, 1901) (Crustacea, Tanaidacea) como indicador biológico de calidad del agua en un estuario templado de Sudamérica

Sinelobus stanfordi (Richardson, 1901) es un tanaidáceo eurihalino distribuido mundialmente y registrado en el sector de agua dulce del estuario del Río de la Plata. A pesar de la vasta bibliografía disponible sobre esta especie, su sensibilidad a la contaminación no ha sido evaluada anteriormente. Este estudio se llevó a cabo en la zona intermareal de la porción dulceacuícola del estuario del Río de La Plata, abarcando aproximadamente $170 \mathrm{~km}$ de la costa argentina sometida a diferentes tipos de perturbaciones antropogénicas. Las muestras bentónicas fueron tomadas estacionalmente por triplicado en la zona vegetada, a lo largo de 19 sitios de muestreo entre 2005-2010. Con el objeto de explorar los gradientes ambientales dentro de esta área, se realizó un Análisis de Componentes Principales (PCA). Para la interpretación de las variables más relevantes, los ejes definidos por el PCA fueron sometidos a una "varimax-rotation" normalizada. Se analizaron los óptimos 
ecológicos y límites de tolerancia de S. stanfordi para cada variable ambiental. El análisis multivariado sugirió que la mayor parte de la variación en el área de estudio se debe tanto al impacto de la contaminación antrópica como a la dinámica natural del estuario. La abundancia de la especie fue significativamente menor en los sitios con alto contenido de nutrientes y demandas de oxígeno, exhibiendo una correlación negativa con el contenido de fosforo disuelto y una correlación positiva con los niveles de oxígeno. La conductividad y la turbidez del agua no representaron variables limitantes en la distribución de esta especie.

Este estudio constituye el primer aporte para la evaluación de los efectos de los disturbios antropogénicos sobre las poblaciones de este crustáceo y contribuye al conocimiento de la ecología de los tanaidáceos. Las bajas abundancias de la especie registradas en los sitios más contaminados sugerirían que S. stanfordi podría ser útil en estudios de biomonitoreo en el estuario del Río de La Plata como así también en otros sistemas estuarinos templados.

Palabras clave: Tanaidacea, Sinelobus stanfordi, ecología y distribución, disturbios antropogénicos, biomonitoreo, estuario del Río de la Plata, Argentina.

\section{INTRODUCTION}

Peracarid crustaceans constitute one of the dominant components of coastal ecosystems and play a relevant ecological role in the structure and function of benthic assemblages. Because of their sensitivity to several pollutants and to water physicochemical variations, these crustaceans have been regarded as potential indicators of pollution (Conradi \& López-Gonzalez, 2001; Esquete et al., 2011).

Sinelobus stanfordi (Richardson, 1901) is a tanaid found worldwide over a broad range of salinities, from hypersaline lakes (Gardiner, 1975) to freshwater systems (Jaume \& Boxshall, 2008). This euryhaline species is of great relevance in coastal trophic chains as it represents a major food source for migratory birds and fish of commercial interest (Sewell, 1996; Aguirre-León \& Díaz-Ruiz, 2000). This tanaid elaborates its tubes in diverse kinds of substrata. Although it is mainly present in soft bottoms, it also occurs on hard substrata colonised by other invertebrate species such as the balanoids and the invasive mussel Limnoperna fortunei (Dunker, 1857) (Spaccesi \& Rodrigues Capítulo, 2012). Sinelobus stanfordi has also frequently been associated with macrophytes, whose surfaces are used for the formation of its tubes (Dos Santos, 2000).

Estuaries are critical sites of conservation and productivity mainly because they provide breeding and rearing sites for several commercially important fish and stopover locations for migratory birds (Day et al., 1989). These areas provide valuable goods and services in terms of ecosystem trophic linkages, biodiversity, and biogeochemical cycles. The Río de la Plata is an extensive, shallow, and micro tidal coastal plain estuary that constitutes a system of great socioeconomic relevance, representing one of the main navigation routes of South America and a vast reservoir of freshwater. This estuary is divided into a freshwater area that covers approximately $13000 \mathrm{~km}^{2}$ and a mixohaline zone. Along the Argentine coast, the freshwater portion contains a high degree of urbanisation and industrialisation that generates massive inputs of pollutants that represent a threat to both human health and aquatic biota. The presence of heavy metals, organochlorine pesticides, polychlorinated biphenyls, and hydrocarbons, as well as nutrients, organic matter, and pathogenic agents has been reported in the estuary (AA, AGOSBA, ILPLA, SHIN, 1997; Colombo et al., 2005, 2006). Moreover, constructions along the coastline combined with dredging and other modifications of the hydrologic regime of the coastal wetlands have altered the coastal morphology and interfered with the natural processes of the shoreline dynamics, thus undermining the integrity of the physical habitat (Gómez et al., 2009; Armendáriz et al., 2011). Nevertheless, natural reserves and wildlife protection areas are also present in this area and constitute key centres for the conservation of biodiversity (Gómez \& Rodrigues Capítulo, 2000). 
Several studies have been conducted to describe the benthic assemblages of the Río de la Plata estuary (Rodrigues Capítulo et al., 1998, Giberto et al., 2004; Cortelezzi et al., 2007; Ocón et al., 2008; Armendáriz et al., 2011; Spacessi \& Rodrigues Capítulo, 2012). In the benthic coastal communities of this system, $S$. stanfordi constitutes a species native to both Argentina (Taberner, 1983; César et al., 2000) and Uruguay (Giménez et al., 2005). This tanaid, however, has been reported as an invasive species in several countries (Heiman et al., 2008; Van Haaren \& Soors, 2009). Despite the wide distribution of this species, only scant information is available about the range of environmental variables that $S$. stanfordi can tolerate. Therefore, a wider knowledge of the parameters that determine the presence and persistence of this species within a given environment is needed. Accordingly, the aim of this study was to analyse the following two ecological features of $S$. stanfordi in the freshwater sector of the Río de la Plata estuary: (1) the ecological optimum and tolerance ranges for the variables studied and (2) the effects of water quality on the populations of this tanaid. These results could provide a baseline of data for predicting the vulnerability of other estuaries to the invasion of this species as well as constitute valuable information for assessing the ecological status of the Río de la Plata estuary.

\section{METHODS}

\section{Study area}

The Río de la Plata estuary receives freshwater from the second largest watershed in South America (i.e., the del Plata basin, a 3.2 million $\mathrm{km}^{2}$ area encompassing territories within Argentina, Bolivia, Brazil, Paraguay, and Uruguay). This funnel-shaped estuary is $320 \mathrm{~km}$ long and covers an area of $35000 \mathrm{~km}^{2}$. The dynamic of the estuary is controlled mainly by the tides (with tidal amplitude ranging from 30 to $100 \mathrm{~cm}$ ), winddriven waves, and continental runoff.

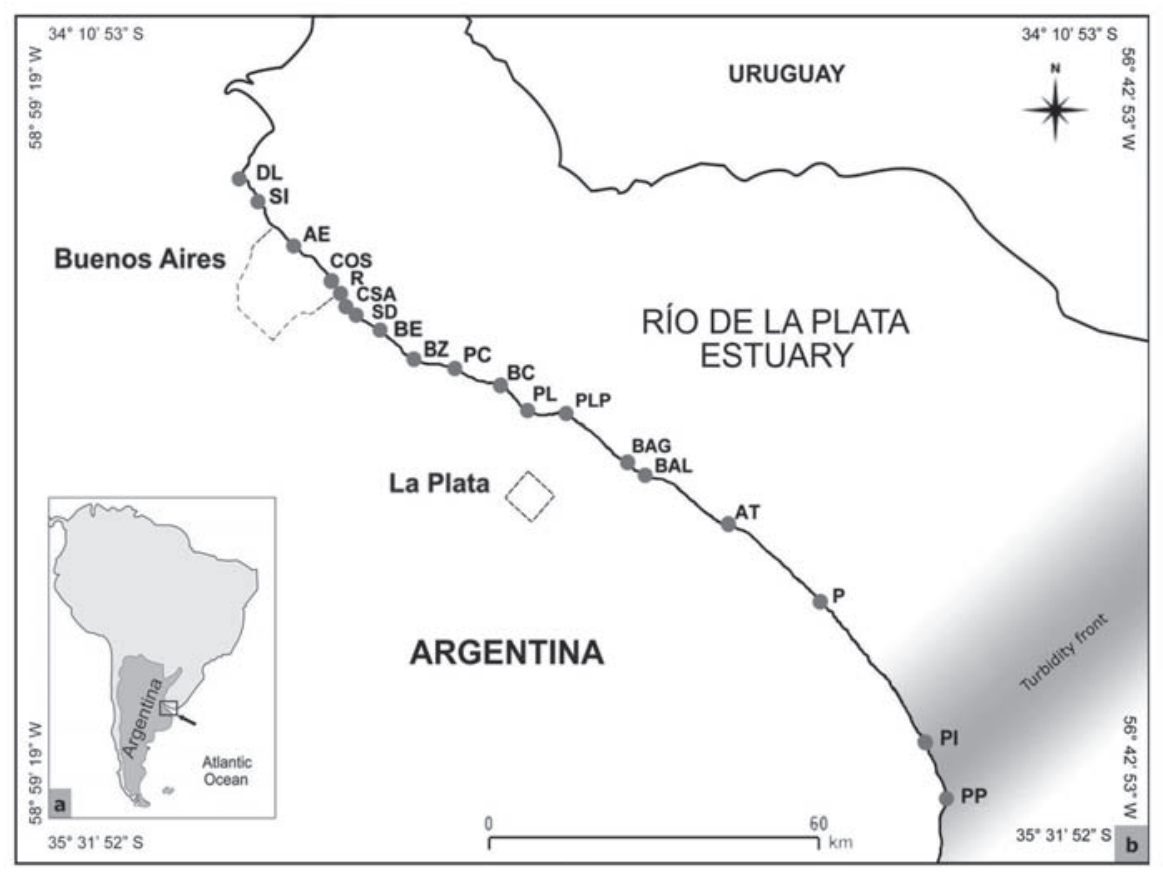

Figure 1. a. Location of the Río de la Plata estuary system in South America, and b. Map of the study area showing the sampling sites. Large urban areas are indicated. a. Ubicación del estuario del Río de La Plata en Sudamérica y b. Mapa del área de estudio mostrando los sitios de muestreo. Se indican las grandes áreas urbanas. 
The spatial succession of the aquatic vegetation between the aquatic and terrestrial ecosystems is dominated by the bulrush Schoenoplectus californicus (Meyer) Soják. The stands of this bulrush constitute a refuge zone for various vertebrate and invertebrate species (Gómez \& Rodrigues Capítulo, 2000).

The surface sediments of the intertidal zone of the Río de la Plata consist mainly of fine and very fine $(62.5-250 \mu \mathrm{m})$ sand, leading to the predominance of clay and silt fractions as well as a high organic matter content as a consequence of anthropogenic impacts along the coast (Gómez et al., 2009).

According to its dynamics and geomorphologic characteristics, the Río de la Plata is divided into an inner and outer region, with fresh and brackish water, respectively. The present study was conducted in the inner region, along the Argentine coastline of the southern coastal fringe of the Río de la Plata estuary zone, covering approximately $180 \mathrm{~km}$ (between the coordinates $34^{\circ} 27^{\prime} 10^{\prime \prime} \mathrm{S} ; 58^{\circ} 30^{\prime} 21^{\prime \prime} \mathrm{W}$ and $35^{\circ} 23^{\prime} 28^{\prime \prime} \mathrm{S} ; 57^{\circ}$ $\left.08^{\prime} 50^{\prime \prime} \mathrm{W}\right)$ (Fig. 1).

\section{Sampling sites}

The 19 sampling sites were selected according to the influence of different kinds of land use, encompassing $170 \mathrm{~km}$ of shoreline (Fig. 1, Table 1). The northernmost sites (DL, SI, AE, COS, R, CSA, SD, BE) are exposed directly to the impact of the city of Buenos Aires, where navigational and port activities take place and domestic and industrial wastes are discharged. Sites BZ and PC are located near the sewage effluents of Buenos Aires. The Berazategui sewer (site BZ) serves more than 12 million inhabitants, discharging more than 3 million $\mathrm{m}^{3} /$ day of urban and industrial effluents without any wastewater treatment. Site BC is situated in the protected natural reserve Selva Marginal de Punta Lara and site PL is exposed mainly to recreational and fishing activities. Sites PLP and

Table 1. Code names for the sampling sites, and their locations along the coast of the Río de la Plata estuary. Códigos y ubicación de los sitios de muestreo a lo largo de la costa del estuario del Río de La Plata.

\begin{tabular}{|c|c|c|}
\hline Site code & Site name & Coordinates \\
\hline DL & Desembocadura de Luján & $34^{\circ} 27^{\prime} 10^{\prime \prime} \mathrm{S} ; 58^{\circ} 30^{\prime} 21^{\prime \prime} \mathrm{W}$ \\
\hline SI & San Isidro & $34^{\circ} 29^{\prime} 08^{\prime \prime} \mathrm{S} ; 58^{\circ} 28^{\prime} 49^{\prime \prime} \mathrm{W}$ \\
\hline $\mathrm{AE}$ & Aeroparque & $34^{\circ} 32^{\prime} 57^{\prime \prime} \mathrm{S} ; 58^{\circ} 25^{\prime} 35^{\prime \prime} \mathrm{W}$ \\
\hline COS & Costanera Sur & $34^{\circ} 36^{\prime} 54^{\prime \prime} \mathrm{S} ; 58^{\circ} 20^{\prime} 24^{\prime \prime} \mathrm{W}$ \\
\hline $\mathrm{R}$ & Matanza-Riachuelo & $34^{\circ} 37^{\prime} 42^{\prime \prime} \mathrm{S} ; 58^{\circ} 19^{\prime} 48^{\prime \prime} \mathrm{W}$ \\
\hline CSA & Canal Sarandí & $34^{\circ} 39^{\prime} 31^{\prime \prime} \mathrm{S} ; 58^{\circ} 18^{\prime} 59^{\prime \prime} \mathrm{W}$ \\
\hline SD & Canal Santo Domingo & $34^{\circ} 40^{\prime} 01^{\prime \prime} \mathrm{S} ; 58^{\circ} 18^{\prime} 04^{\prime \prime} \mathrm{W}$ \\
\hline $\mathrm{BE}$ & Bernal & $34^{\circ} 41^{\prime} 30^{\prime \prime} \mathrm{S} ; 58^{\circ} 15^{\prime} 14^{\prime \prime} \mathrm{W}$ \\
\hline $\mathrm{BZ}$ & Berazategui & $34^{\circ} 44^{\prime} 38^{\prime \prime} \mathrm{S} ; 58^{\circ} 10^{\prime} 42^{\prime \prime} \mathrm{W}$ \\
\hline $\mathrm{PC}$ & Punta Colorada & $34^{\circ} 45^{\prime} 11^{\prime \prime} \mathrm{S} ; 58^{\circ} 06^{\prime} 27^{\prime \prime} \mathrm{W}$ \\
\hline $\mathrm{BC}$ & Boca Cerrada & $34^{\circ} 46^{\prime} 49^{\prime \prime} \mathrm{S} ; 58^{\circ} 00^{\prime} 59^{\prime \prime} \mathrm{W}$ \\
\hline PL & Punta Lara & $34^{\circ} 49^{\prime} 29^{\prime \prime} \mathrm{S} ; 57^{\circ} 57^{\prime} 35^{\prime \prime} \mathrm{W}$ \\
\hline PLP & Puerto La Plata & $34^{\circ} 50^{\prime} 01^{\prime \prime} \mathrm{S} ; 57^{\circ} 52^{\prime} 50^{\prime \prime} \mathrm{W}$ \\
\hline BAG & Bagliardi & $34^{\circ} 52^{\prime} 26^{\prime \prime} \mathrm{S} ; 57^{\circ} 48^{\prime} 33^{\prime \prime} \mathrm{W}$ \\
\hline BAL & Balandra & $34^{\circ} 55^{\prime} 44^{\prime \prime} \mathrm{S} ; 57^{\circ} 42^{\prime} 56^{\prime \prime} \mathrm{W}$ \\
\hline AT & Atalaya & $35^{\circ} 00^{\prime} 49^{\prime \prime} \mathrm{S} ; 57^{\circ} 32^{\prime} 07^{\prime \prime} \mathrm{W}$ \\
\hline $\mathrm{P}$ & Pearson & $35^{\circ} 07^{\prime} 27^{\prime \prime} \mathrm{S} ; 57^{\circ} 22^{\prime} 53^{\prime \prime} \mathrm{W}$ \\
\hline PI & Punta Indio & $35^{\circ} 16^{\prime} 45^{\prime \prime} \mathrm{S} ; 57^{\circ} 13^{\prime} 19^{\prime \prime} \mathrm{W}$ \\
\hline $\mathrm{PP}$ & Punta Piedras & $35^{\circ} 23^{\prime} 28^{\prime \prime} \mathrm{S} ; 57^{\circ} 08^{\prime} 50^{\prime \prime} \mathrm{W}$ \\
\hline
\end{tabular}


BAG are located close to the port and to sewer outfalls from another large urban centre (the city of La Plata), respectively. Sites BAL, AT, P, PI, and PP are minimally affected by human activity, as these sites are exposed to small-scale recreational, fishing, and rural activities. Sites PI and PP are the closest to the maximal-turbidity zone of the estuary and to the beginning of its oligohaline portion.

\section{Sampling and laboratory analyses}

Benthic samples within the intertidal zone were collected seasonally at low tide from 2005-2010. Sampling sites were georeferenced and visited at least six times within the study period. At each sampling opportunity, benthic samples were randomly obtained with an Ekman grab (coverage of $100 \mathrm{~cm}^{2}$ ) in vegetated areas within stands of the bulrush $S$. californicus. At all sites, triplicate samples were taken and fixed in situ with $5 \%(\mathrm{v} / \mathrm{v})$ formaldehyde. The following physical and chemical variables were measured in the field at each sampling opportunity: temperature $\left({ }^{\circ} \mathrm{C}\right)$ and $\mathrm{pH}$ (Hanna HI 8633), conductivity $(\mu \mathrm{S} / \mathrm{cm}$, Lutron CD-4303), dissolved oxygen (expressed as \% DO saturation, Oxymeter 600-ESD), and turbidity (NTU [nephelometric turbidity units], Turbidity Meter 800-ESD). Water samples were also taken for nutrient analysis (nitrates: $\mathrm{NO}_{3}-\mathrm{N}$, nitrites: $\mathrm{NO}_{2}-\mathrm{N}$, ammonium: $\mathrm{NH}_{4}-\mathrm{N}$ and soluble reactive phosphorous: SRP; all in $\mathrm{mg} / \mathrm{l}$ ) and biochemical and chemical oxygen demand analysis $\left(\mathrm{BOD}_{5}\right.$ and COD, respectively; APHA, 1998).

In the laboratory, the benthic material was washed on a $250 \mu \mathrm{m}$ mesh sieve and stained with erythrosin B. Individuals of $S$. stanfordi were identified according to Lopretto \& Tell (1995), sorted, and counted under a stereoscopic microscope.

\section{Data analyses}

The main environmental gradients within the study area were investigated by principal component analysis (PCA) based on the physicochemical variables using the Statistica 6.0 software (StatSoft Inc. 2001). To ensure that all variables had an equal weight in the analysis (Pla, 1986), the environmental data were previously standardised $($ Std. Score $=($ raw score - mean $) / S t d$. deviation). The principal components (PCs) with eigenvalues greater than one were retained. A varimax-normalised rotation of the axis defined by PCA was conducted to reveal those variables that had the strongest correlations with the retained axis (Singh et al., 2004). The new group of variables extracted through rotation are known as Varifactors (VFs). According to Liu et al. (2003), the factor loadings were classified as "strong", "moderate", and "weak", corresponding to the absolute loading values of $>0.75,0.75-0.50$ and $0.50-0.30$, respectively.

A two-way factorial MANOVA test was performed to assess temporal and spatial differences for each environmental variable within the study area. Data was $\log _{10}(X+1)$ transformed to approximate the variables to a normal distribution. The Shapiro-Wilk test was computed for the multivariate analysis as well as for the univariate tests, and the Newman-Keuls test was applied a posteriori.

A two-way ANOVA was performed to evaluate the temporal and spatial differences in the abundance of the species. The seasonal variation was analysed using the sampling dates as multiple input data and the spatial variation was analysed using the sampling sites as multiple input data. The a posteriori Student-Newman-Keuls test was applied when statistically significant differences were found (Underwood, 2007).

Statistical analyses were performed with the significance level set at $p<0.05$ using the Statistica 6.0 software (StatSoft Inc. 2001).

The ecological optima and tolerance ranges of S. stanfordi for the environmental variables were calculated. The environmental variables were log-transformed to approximate a normal distribution. Weighted average estimates of the species optima $\left(u_{k}\right)$ were calculated on the basis of the abundance of the species in each sample (Potapova \& Charles, 2003; Rossaro et al., 2006):

$$
u_{k}=\frac{\sum_{i=1}^{n} y_{i k} x_{i}}{\sum_{i=1}^{n} y_{i k}}
$$


where $y_{i k}$ is the relative abundance of species $k$ in the sample $i, x$ is the value of the environmental parameter in sample $i$, and $n$ is the total number of samples in the data set.

The tolerance or weighted standard deviation $\left(t_{k}\right)$ was calculated (Potapova \& Charles, 2003; Rossaro et al., 2006):

$$
t_{k}=\sqrt{\frac{\sum_{i=1}^{n} y_{i k}\left(x_{i}-u_{k}\right)^{2}}{\sum_{i=1}^{n} y_{i k}}}
$$

where $u_{k}$ is the weighted average estimate of the species optima mentioned above.

Spearman's rank-order correlation was performed to establish the relationships between the relative abundance of $S$. stanfordi and each environmental variable measured. Correlations with a $p<0.05$ are reported in the text. Statistica 6.0 software (StatSoft Inc. 2001) was used for data analysis.

\section{RESULTS}

\section{Water quality}

The PCA of the entire data set yielded four PCA axes with eigenvalues $>1$, without significant correlations with the input variables (loading $<0.70)$. The varimax-normalised rotation of the PCA axes still retained four different VFs, explaining $69 \%$ of the total variance (Fig. 2). The physicochemical variables exhibited large variations throughout the study area. Table 2 lists the average and corresponding standard deviation values for each of the environmental variables measured. According to the MANOVA, the variables \% DO saturation, $\mathrm{DBO}_{5}, \mathrm{SRP}, \mathrm{NH}_{4}-\mathrm{N}$, $\mathrm{NO}_{2}-\mathrm{N}$, and $\mathrm{NO}_{3}-\mathrm{N}$ showed significant temporal differences $(p<0.05)$. During the warmest period, the \% DO saturation and the $\mathrm{NO}_{3}-\mathrm{N}$ concentrations were higher, whereas the $\mathrm{DBO}_{5}$ and the $\mathrm{NO}_{2}-\mathrm{N}$ concentrations were higher in winter and spring. All the physicochemical variables analysed showed significant spatial differences $(p<0.05)$. For the VF1 of the PCA, the highest
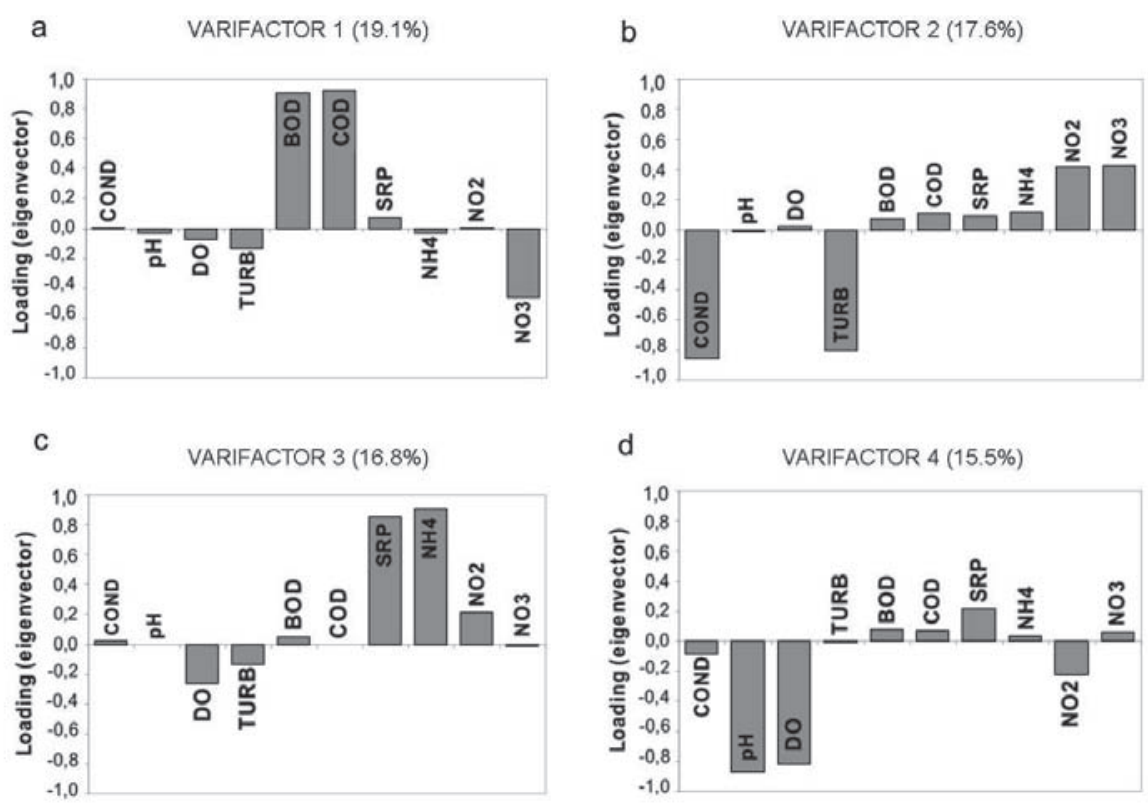

Figure 2. Loadings of experimental variables on the first four rotated axes of the PCA for the complete data set. Cargas de las variables experimentales en los primeros cuatro ejes rotados del PCA para el set completo de datos. 


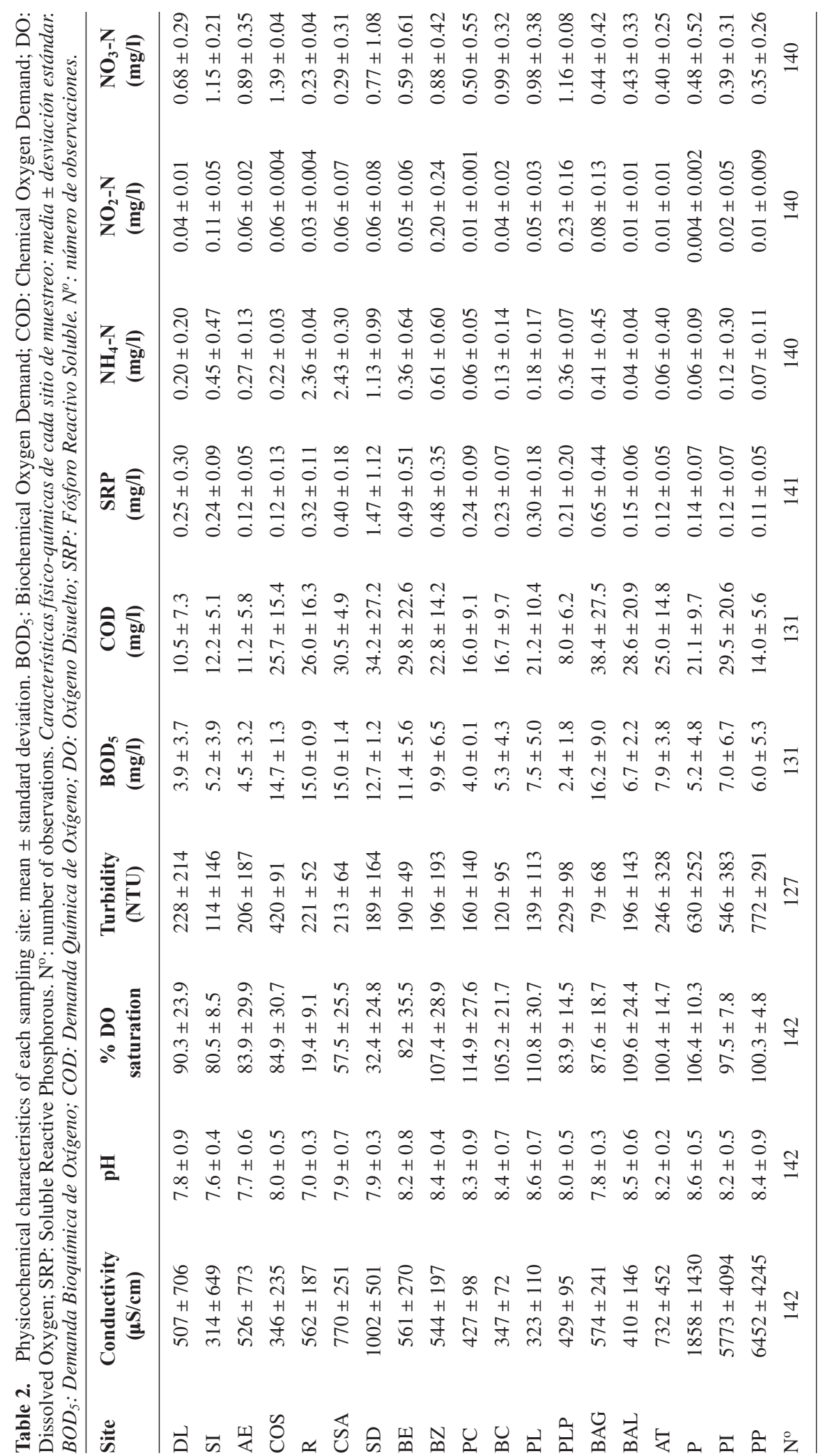


values of $\mathrm{BOD}_{5}(>10 \mathrm{mg} / \mathrm{l})$ and $\mathrm{COD}(>25 \mathrm{mg} / \mathrm{l})$ were registered at the most polluted sites (COS, R, CSA, SD, BE, BZ, and BAG). By contrast, in accordance with the VF2 of the PCA, which is related to a natural conductivity and turbidity gradient, the highest mean values of such variables $(>1800 \mu \mathrm{S} / \mathrm{cm}$ and $>500 \mathrm{NTU}$, respectively) were recorded in the outer estuary (sites P, PI, and PP); however, conductivity values were also high at sites SD $(>1000 \mu \mathrm{S} / \mathrm{cm})$ and CSA $(>750 \mu \mathrm{S} / \mathrm{cm})$, where locations correspond to areas that receive mainly industrial and/or domestic discharges. The nutrient contents were in general recorded at low concentrations at the most external sites of the estuary (i.e., BAL, AT, $\mathrm{P}, \mathrm{PI}$, and $\mathrm{PP})$. The higher $\mathrm{NO}_{2}-\mathrm{N}$ concentrations $(>0.2 \mathrm{mg} / \mathrm{l})$ were recorded at sites PLP and BZ where a major sewage-discharge area is located. The highest concentrations of $\mathrm{NH}_{4}-\mathrm{N}$ were measured at sites R, CSA, and SD ( $>1 \mathrm{mg} / \mathrm{l})$ and the higher SRP concentrations $(>0.5 \mathrm{mg} / \mathrm{l})$ were recorded at sites $\mathrm{CSA}, \mathrm{SD}, \mathrm{BE}, \mathrm{BZ}$, and BAG during most sampling events; the last two variables were related to the VF3 of the PCA at the time. Sites R, CSA, and SD showed \% DO saturation values lower than $60 \%$ (variable related to VF4 of the PCA).

\section{Ecological optima and tolerance limits of S. stanfordi}

The ecological optima and tolerance limits for all the environmental variables measured are shown in Table 3. This species was associated with a relatively high conductivity (optimum at $658 \mu \mathrm{S} /$ $\mathrm{cm}$ ) and turbidity (optimum at $143 \mathrm{NTU}$ ). The ecological optimum and tolerance limits to $\mathrm{pH}$ corresponded to alkaline water (optimum at 8.1). The abundance of $S$. stanfordi was related to low concentrations of $\mathrm{BOD}_{5}$ (optimum at $4.5 \mathrm{mg} / \mathrm{l}$ ) and COD (optimum at $13.9 \mathrm{mg} / \mathrm{l}$ ). By contrast, the abundance of the species exhibited a significant positive correlation with increases in oxygen levels (optimum at $94 \%$ saturation, $r$ : 0.21 , $p$ : 0.01) that may even reach values of supersaturation. With respect to the forms of inorganic nitrogen, this tanaid showed a high ecological tolerance limit for $\mathrm{NO}_{3}-\mathrm{N}$ concentrations
Table 3. Sinelobus stanfordi ecological optima and tolerance limits (low, L and high, H) for Conductivity, pH, Dissolved Oxygen (as \% DO saturation), Turbidity, Biochemical and Chemical Oxygen Demands $\left(\mathrm{BOD}_{5}\right.$ and $\mathrm{COD}$, respectively), and nutrients $\left(\mathrm{NO}_{3}-\mathrm{N}, \mathrm{NO}_{2}-\mathrm{N}, \mathrm{NH}_{4}-\mathrm{N}, \mathrm{SRP}\right)$. Valores de óptimos y límites de tolerancia ecológicos (inferior, L y superior, $H$ ) de Sinelobus stanfordi para Conductividad, $\mathrm{pH}$, Oxígeno Disuelto (como \% de saturación de Oxígeno), Turbidez, Demandas Bioquímica y Química de Oxígeno $\left(B_{0} O D_{5}\right.$ y $C O D$, respectivamente) y nutrientes $\left(\mathrm{NO}_{3}-\mathrm{N}, \mathrm{NO}_{2}-\mathrm{N}, \mathrm{NH}_{4}-\mathrm{N}, \mathrm{SRP}\right)$.

\begin{tabular}{|c|c|c|c|}
\hline & Optimum & $\mathbf{L}$ & $\mathbf{H}$ \\
\hline Conductivity $(\mu \mathrm{S} / \mathrm{cm})$ & 658 & 207 & 2089 \\
\hline pH & 8.1 & 7.6 & 8.6 \\
\hline$\%$ DO saturation & 94 & 77 & 116 \\
\hline Turbidity (NTU) & 143 & 27 & 750 \\
\hline BOD $_{5}(\mathrm{mg} / \mathrm{l})$ & 4.5 & 1.8 & 11.2 \\
\hline COD (mg/l) & 13.9 & 7.0 & 27.7 \\
\hline $\mathrm{NO}_{3}-\mathrm{N}(\mathrm{mg} / \mathrm{l})$ & 0.469 & 0.145 & 1.522 \\
\hline $\mathrm{NO}_{2}-\mathrm{N}(\mathrm{mg} / \mathrm{l})$ & 0.017 & 0.004 & 0.068 \\
\hline $\mathrm{NH}_{4}-\mathrm{N}(\mathrm{mg} / \mathrm{l})$ & 0.043 & 0.005 & 0.337 \\
\hline SRP (mg/l) & 0.156 & 0.096 & 0.254 \\
\hline
\end{tabular}

$(\mathrm{H}=1.55 \mathrm{mg} / \mathrm{l})$, with an optimum at $0.47 \mathrm{mg} / \mathrm{l}$ and became associated with low concentrations of $\mathrm{NO}_{2}-\mathrm{N}$ (optimum at $0.02 \mathrm{mg} / \mathrm{l}$ ) and $\mathrm{NH}_{4}-\mathrm{N}$ (optimum at $0.04 \mathrm{mg} / \mathrm{l}$ ). The abundance of the species exhibited a significant negative correlation with increases in the concentration of SRP (optimum at $0.16 \mathrm{mg} / \mathrm{l}, r$ : $-0.22, p$ : 0.009).

\section{Abundance and distribution of $S$. stanfordi}

The results of the two-way ANOVA test performed to analyse variations in the abundance of $S$. stanfordi showed statistically significant differences between "stations" $(p<0.05)$, but no seasonal variations in the abundance were found $(p=0.783)$. The higher mean abundance values were recorded at the most external sites of the estuary $\left(>3200 \mathrm{ind} / \mathrm{m}^{2}\right)$, whereas the lowest occurred at sites COS (200 ind $\left./ \mathrm{m}^{2}\right)$ and CSA $\left(15 \mathrm{ind} / \mathrm{m}^{2}\right)$. In sites $\mathrm{R}, \mathrm{SD}, \mathrm{BE}$, and PLP, no individuals were found. Figures $3 \mathrm{a}-\mathrm{d}$ show the mean values for several of the most influential variables on the distribution of this tanaid (i.e., \% DO saturation, $\mathrm{BOD}_{5}, \mathrm{SRP}$, and $\mathrm{NH}_{4}-\mathrm{N}$ ) along with the maximal, minimal, and ecological optimal levels for its survival throughout the study area. Figure $3 \mathrm{e}$ summarises the mean abundance values of 

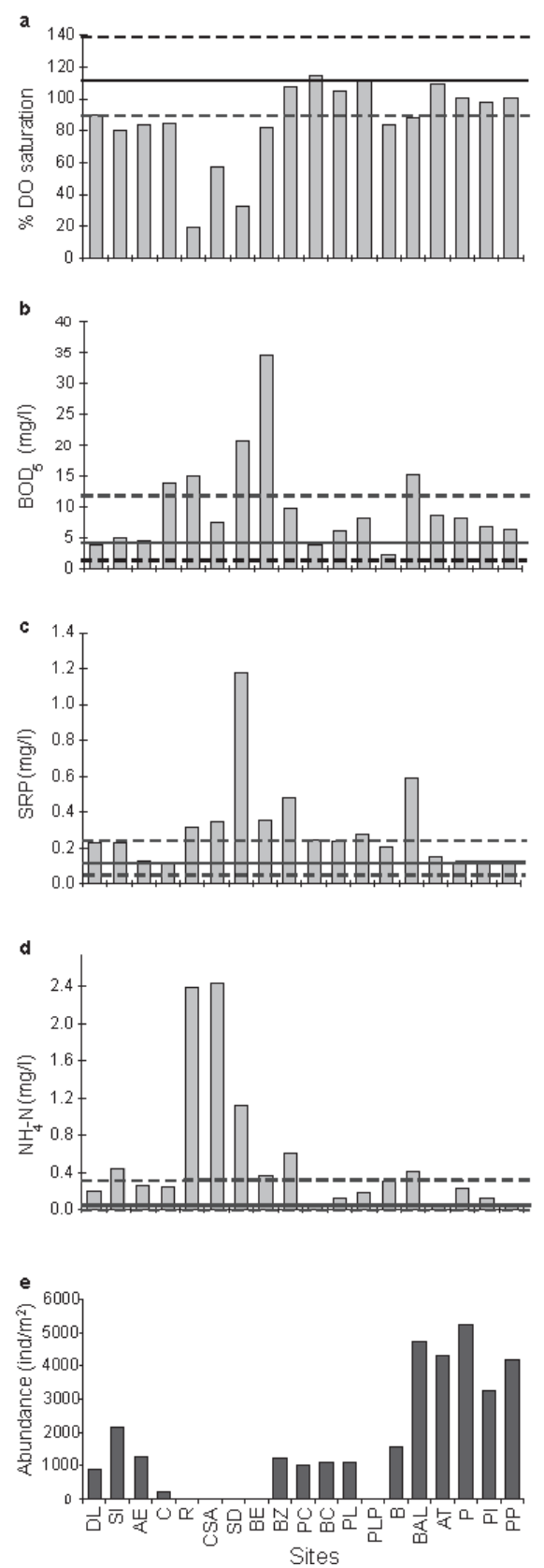

Figure 3. Mean values of a: \% saturation of Dissolved Oxygen, b: $\mathrm{BOD}_{5}$, c: SRP concentrations, d: $\mathrm{NH}_{4}-\mathrm{N}$ concentrations, and e: abundance of Sinelobus stanfordi. The continuous line corresponds to the ecological optimum and the dotted lines to the higher and lower tolerance limits $(\mathrm{H}$ and $\mathrm{L})$ of this species. Valores medios de a: \% de saturación de Oxígeno, $b: B O D_{5}$, c: concentraciones de SRP, d: concentraciones de $\mathrm{NH}_{4}-\mathrm{N}$, y e: abundancia de Sinelobus stanfordi. Las líneas continuas corresponden a los valores óptimos ecológicos y las líneas punteadas a los límites de tolerancia superior e inferior (H y L) de la especie.
S. stanfordi at the same respective sampling sites. A comparison of figure $3 \mathrm{e}$ with figures $3 \mathrm{a}-\mathrm{d}$ reveals the correspondence between the presence or absence of this species and the habitability of the environment at each of the sampling sites.

\section{DISCUSSION}

According to the multivariate analysis, most of the variations within the study area could be related to the impact of anthropogenic pollution as well as the natural dynamics of the estuary. Similar results were obtained by Gómez et al. $(2009 ; 2012)$ for the same region of the Río de la Plata estuary.

Sinelobus stanfordi showed higher species abundance in coastal environments with high oxygen levels and low nutrient concentrations. This euryhaline species was recorded during all seasons and throughout the entire length of the freshwater sector of the estuary, except in highly impacted sites.

The higher densities of $S$. stanfordi were recorded in the outer estuary at sites barely affected by human activities, having high dissolved oxygen levels (BAL, AT, P, PI, PP) and characterised by a greater maintenance of the native state of that portion of the coast. By contrast, at those sites with greater urban and industrial development (COS, R, CSA, SD, BE) and nearby sewage outfalls (BZ, PC, BAG), S. stanfordi was either present in low numbers or absent. Levels of heavy metals generally higher than the permissible exposure limit (PEL) were recorded at sites R, CSA, and SD (Lammel et al., 1997; FREPLATA, 2005; INA 2011). Although there are no data about the tolerance of this species to heavy metals, the presence of those pollutants could affect $S$. stanfordi and lead to a decrease of the population size at those sites. The low species abundance registered in the three northernmost sites (DL, SI, and AE) might have resulted not only from the effect of human activities along the coast but also from the input of poor quality water from the Lujan River, which receives freshwater from the Reconquista River, one of the most polluted rivers in Argentina (Salibián, 2006; Ron- 
co et al., 2008). Populations of other tanaids have likewise been found to decrease in response to anthropogenic impacts. The abundance of Kalliapseudes schubartii, for example, was also lower in zones affected by human development than in protected areas of southeastern Brazil (Pagliosa \& Barbosa, 2006). Although site BC is located in a protected area, the observed abundance of $S$. stanfordi was low; this is most likely due not only to local anthropogenic impact but also to an impact received from upstream waters.

The ecological optimum and the wide tolerance range that $S$. stanfordi exhibited for conductivity highlights its euryhaline character -a property that is assisted by the presence of a special ion-transport tissue in the gills that allows an extensive degree of osmotic regulation (Kikuchi \& Matsumasa, 1993). This feature facilitates the colonisation of new ecological niches and makes $S$. stanfordi an effective species for the invasion of different habitats including marine, brackish, and freshwater systems (Van Haaren \& Soors, 2009). Moreover, the species was recently found at conductivity values lower than $60 \mu \mathrm{S} / \mathrm{cm}$ in the Uruguay river, approximately $150 \mathrm{~km}$ upstream from the river's confluence with the Paraná river, another main tributary of the Río de la Plata $\left(33^{\circ} 6.1^{\prime} \mathrm{S}\right.$; 58 $17.9^{\prime} \mathrm{W}$, Rodrigues Capítulo, personal communication).

Some tanaidacean species have been regarded as good indicators of environmental quality. Kalliapseudes schubartii, for example, exhibited sub-lethal responses (inability to build tubes and decreased movement capacity) after its exposure to sediments containing petroleum products (Brendolan, 2004). Although no laboratory assays were conducted in this study, field data show the detrimental influence of high levels of $\mathrm{NH}_{4}-\mathrm{N}$ and SRP as well as of oxygen demands on the abundance of $S$. stanfordi. Furthermore, at those sites where these parameters showed values higher than the upper ecological limits that this species could tolerate, the species was either absent or present with a very low abundance. Recently, as a result of its fidelity in reflecting environmental changes, $S$. stanfordi was included in a biotic-integrity index for evaluating the coastal freshwater tidal zone of the Río de la Plata es- tuary (i.e., the IBIRP, Gómez et al., 2012). Accordingly, although further field and laboratory analysis should be conducted, we suggest that the abundance of $S$. stanfordi might be considered a sensitivity indicator in terms of organic pollution, as demonstrated by its narrow ecological tolerance range for organic pollution variables.

The present investigation thus constitutes the first approach in the form of a field study to assess the relationship between the density of $S$. stanfordi and the environmental variables in sites under different kinds of anthropogenic disturbance in a temperate estuary. This work also provides information about the ecological optima and tolerance ranges of $S$. stanfordi for different environmental variables (i.e., both natural and stress factors). Our results therefore constitute basic background information that would be helpful for general biomonitoring studies of the Río de la Plata as well as for other similar estuarine systems.

\section{CONCLUSIONS}

The ecological optima and tolerance ranges of $S$. stanfordi for the environmental variables analysed suggested that the species could be considered a sensitivity indicator in terms of organic pollution and would be useful for water quality assessments in the coastal sector of this temperate estuary. This information could also be helpful in predicting the possible effects of $S$. stanfordi on native populations of other similar bodies of water in future research. Laboratory assays, however, should be conducted to broaden the ecological preference knowledge and physiological tolerance ranges of this species.

\section{ACKNOWLEDGEMENTS}

This research has been financed through a grant from CONICET (PIP No 0341) and Agencia Nacional de Promoción Científica y Tecnológica, FONCYT 2007-2010 (PICT N 32077 and 33939). We would like to express our thanks to members of the Laboratory of Benthos of the ILPLA for technical assistance in the field 
and to Jorge Donadelli from the Laboratory of Chemistry (ILPLA) for the nutrient and oxygen-demand analysis of the water samples. We would also like to acknowledge the editor's and anonymous reviewer's comments which substantially improved our manuscript and Dr. Inés César (MLP) for the bibliography supplied. Finally, the authors are grateful to Dr. Donald F. Haggerty, a retired career investigator and native English speaker, for editing the final version of the manuscript. This Scientific contribution No 903 was from the Instituto de Limnología Dr. Raúl A. Ringuelet.

\section{REFERENCES}

AA, AGOSBA, ILPLA, SHIN. 1997. Calidad de las aguas. Franja Costera Sur del Río de la Plata (San Fernando-Magdalena). Consejo Permanente para el Monitoreo de la Calidad de las Aguas de la Franja Costera Sur del Río de la Plata, Buenos Aires, Argentina.

AGUIRRE-LEÓN, A. \& S. DÍAZ-RUIZ. 2000. Population structure, gonadal maturity and feeding habits of Eugerres plumieri (Gerreidae) in the Pomatasta fluvial-deltaic system, Mexico. Ciencias Marinas, 26 (2): 253-273.

AMERICAN PUBLIC HEALTH ASSOCIATION (APHA). 1998. Standard Methods for the examination of Water and Wastewater. American Public Health Association, American Water Works Association and Water Pollution Control Federation.

ARMENDÁRIZ, L. C., A. RODRIGUES CAPÍTULO \& E. S. AMBROSIO. 2011. Relationships between the spatial distribution of oligochaetes (Annelida, Clitellata) and environmental variables in a temperate estuary system of South America (Río de la Plata, Argentina). New Zealand Journal of Marine and Freshwater Research, 45(2): 263-279.

BRENDOLAN, R. A. 2004. Utilização do microcrustáceo Kalliapseudes schubartii em testes de ecotoxicologia. Master's Thesis, Centro de Estudos Gerais, Instituto de Biologia, Mestrado em Biologia Marinha PRH-11. Agência Nacional do Petróleo. Universidade Federal Fluminense, Brasil.

CÉSAR, I., C. OCÓN, A. PAGGI, A. RODRIGUES CAPITULO, F. SPACCESI, M. TANGORRA \& M. P. TASSARA. 2000. Diversidad de inverte- brados bentónicos del Río de la Plata. Biología Acuática, 19: 27-63.

COLOMBO, J. C, N. CAPELLETTI, J. LASCI, M. C. MIGOYA, E. SPERANZA \& C. N. SKORUPKA. 2005. Sources, vertical fluxes and accumulation of aliphatic hydrocarbons in coastal sediments of the Rio de la Plata Estuary, Argentina. Environmental Science and Technology, 39 (21): 8227-8234.

COLOMBO, J. C, N. CAPELLETTI, J. LASCI, M. C. MIGOYA, E. SPERANZA \& C. N. SKORUPKA. 2006. Sources, vertical fluxes and accumulation of aromatic hydrocarbons in coastal sediments of the Rio de la Plata Estuary, Argentina. Environmental Science and Technology, 40 (3): 734-740.

CONRADI, M. \& P. J. LÓPEZ-GONZÁLEZ. 2001.

Relationships between environmental variables and the abundance of peracarid fauna in Algeciras Bay (Southern Iberian Peninsula). Ciencias Marinas, 27 (4): 481-500.

CORTELEZZI, A., A. RODRIGUES CAPÍTULO, L. BOCCARDI \& R. AROCENA. 2007. Benthic assemblages of a temperate estuarine system in South America: Transition from a freshwater to an estuarine zone. Journal of Marine Systems, 68: 569-580.

DAY, J. W., C. HALL, W. KEMP \& A. YÁÑEZARANCIBIA. 1989. Estuarine Ecology. Wiley \& Sons. NY. USA.

DOS SANTOS, N. M. 2000. Abundância sezonal e padroes de ocorrência de Sinelobus stanfordi (Richardson, 1901) (Malacostraca, Tanaidae) no sistema lagunar de Tramandaí, Río Grande do Sul, Brasil. Master's Thesis, Intituto de Biociências, Universidade Federal do Rio Grande do Sul, Brasil.

ESQUETE, P., J. MOREIRA \& J. S. TRONCOSO. 2011. Using peracarid assemblages as an environmental indicator in a protected area with high level of urban pressure (o grove inlet, NW Iberian Peninsula). Proceedings of the 5th Simpósio Brasileiro de Oceanografía. April 17-20. São Paulo, Brasil.

FREPLATA. 2005. Análisis Diagnóstico Transfronterizo del Río de la Plata y su Frente Marítimo. Proyecto "Protección Ambiental del Río de la Plata y su Frente Marítimo: Prevención y Control de la Contaminación y Restauración de Hábitats". Documento Técnico. Proyecto PNUD/GEF RLA/ 99/G 31, Montevideo, Uruguay.

GARDINER, L. F. 1975. A fresh and brackish water tanaidacean Tanais stanfordi (Richardson, 1901), 
from a hypersaline lake in the Galapagos Archipelago, with a report on West-Indian specimens. Crustaceana, 29: 127-140.

GIBERTO, D. A., C. S. BREMEC, E. M. ACHA \& H. MIANZAN. 2004. Large-scale spatial patterns of benthic assemblages in the SW Atlantic: the Río de la Plata estuary and adjacent shelf waters. Estuarine, Coastal and Shelf Science, 61: 1-13.

GIMÉNEZ, L., A. I. BORTHAGARAY, M. RODRÍGUEZ, A. BRAZEIRO \& C. DIMITRIADIS. 2005. Scale-dependent patterns of macrofaunal distribution in soft-sediment intertidal habitats along a large-scale estuarine gradient. Helgoland Marine Research, 59: 224-236.

GÓMEZ, N. \& A. RODRIGUES CAPÍTULO. 2000. La Franja Costera Sur del Río de la Plata. Biología Acuática, 19: 1-6.

GÓMEZ, N., M. LICURSI \& J. COCHERO. 2009. Seasonal and spatial distribution of the microbenthic communities of the Río de la Plata estuary (Argentina) and possible environmental controls. $\mathrm{Ma}$ rine Pollution Bulletin, 58: 878-887.

GÓMEZ, N., M. LICURSI, D. E. BAUER, E. S. AMBROSIO \& A. RODRIGUES CAPÍTULO. 2012. Assessment of biotic integrity of the coastal freshwater tidal zone of a temperate estuary of South America through multiple indicators. Estuaries and Coasts, 35(5): 1328-1339.

HEIMAN, K. W., N. VIDARGAS \& F. MICHELI. 2008. Non-native habitat as a home for non-native species: Comparing communities associated with invasive tubeworm and native oyster reefs. Aquatic Biology, 2: 47-56.

INA (Instituto Nacional del Agua). 2011. Evaluación de la calidad del agua en la franja costera sur del Río de la Plata mediante modelación numérica (Informe técnico). Proyecto "INA 1.207". Ezeiza, Argentina.

JAUME, D. \& G. A. BOXSHALL. 2008. Global diversity of cumaceans \& tanaidaceans (Crustacea: Cumacea \& Tanaidacea) in freshwater. Hydrobiologia, 595: 225-230.

KIKUCHI, S. \& M. MATSUMASA. 1993. Two ultrastructurally distinct types of transporting tissues, the branchiostegal and the gill epithelia, in an estuarine tanaid, Sinelobus stanfordi (Crustacea, Peracarida). Zoomorphology, 113: 253-260.

LAMMEL, E., E. BONFATI \& M. NAVARRO. 1997. Metales pesados. In: Calidad de las aguas. Franja Costera Sur del Río de la Plata (San FernandoMagdalena). AA, AGOSBA, ILPLA, SHIN (ed.):
63-66. Consejo Permanente para el Monitoreo de la Calidad de las Aguas de la Franja Costera Sur del Río de la Plata, Buenos Aires, Argentina.

LIU, C. W., K. H. LIN \& Y. M. KUO. 2003. Application of factor analysis in the assessment of groundwater quality in a blackfoot disease area in Taiwan. Science of the Total Environment, 313: 77-89.

LOPRETTO, E \& G. TELL. 1995. Ecosistemas de aguas continentales. Metodologías para su uso. Tomo III. Ediciones Sur, Argentina.

OCÓN, C., A. RODRIGUES CAPÍTULO \& A. PAGGI. 2008. Evaluation of zoobenthic assemblages and recovery following petroleum spill in a coastal area of Río de la Plata estuarine system, South America. Environmental Pollution, 156: 82-89.

PAGLIOSA, P. R. \& F. A. BARBOSA. 2006. Assessing the environment-benthic fauna coupling in protected and urban areas of southern Brazil. Biological Conservation, 129(3): 408-417.

PLA, L. E. 1986. Análisis Multivariado: Método de Componentes Principales. OEA.

POTAPOVA, M. \& D. F. CHARLES. 2003. Distribution of benthic diatoms in U.S. Rivers in relation to conductivity and ionic composition. Freshwater Biology, 48: 1311-1328.

RODRIGUES CAPÍTULO, A., I. CÉSAR, M. TASSARA, A. C. PAGGI \& M. REMES LENICOV. 1998. Distribution of the macrobenthic fauna of the South Coastal Fringe of the Rio de la Plata River (Argentine): impact of the urban contamination. Verhandlungen des Internationalen Verein Limnologie, 26: 1260-1265.

RONCO, A., L. PELUSO, M. JURADO, G. BULUS ROSSINI \& A. SALIBIÁN. 2008. Screening of sediment pollution in tributaries from the southwestern coast of the Río de la Plata estuary. Latin American Journal of Sedimentology and Basin Analysis, 15 (1): 67-75.

ROSSARO, B., A. BOGGERO, V. LENCIONI, L. MARZIALI \& A. SOLIMINI. 2006. A benthic quality index for Italian lakes. Journal of Limnology, 65: 41-51.

SALIBIÁN, A. 2006. Ecotoxicological assessment of the highly polluted Reconquista River of Argentina. Reviews of Environmental Contamination and Toxicology, 185: 35-65.

SEWELL, M. A. 1996. Detection of the impact of predation by migratory shorebirds: an experimental test in the Fraser River estuary, British Columbia (Canada). Marine Ecology Progress Series, 144: 23-40. 
SINGH, K. P., A. MALIK, D. MOHAN \& S. SINHA. 2004. Multivariate statistical techniques for the evaluation of spatial and temporal variations in water quality of Gomti River (India) -a case study. Water Research, 38(18): 3980-3992.

SPACCESI, F. \& A. RODRIGUES CAPÍTULO. 2012. Benthic communities on hard substrates covered by Limnoperna fortunei Dunker (Bivalvia, Mytilidae) at an estuarine beach (Río de la Plata, Argentina). Journal of Limnology, 71(1): 144-153.

STATSOFT INC. 2001. Statistica for Windows v.6.0.
Data analysis software system. Tulsa, Oklahoma, USA.

TABERNER, R. 1983. Hallazgo de un tanaidáceo del género Kalliapseudes en la costa bonaerense del Rio de La Plata. Neotropica, 29: 2.

UNDERWOOD, A. J. 2007. Experiments in ecology. Their logical design and interpretation using analysis of variance. Cambridge University Press.UK.

VAN HAAREN, T. \& J. SOORS. 2009. Sinelobus stanfordi (Richardson, 1901): a new crustacean invader in Europe. Aquatic Invasions, 4(4): 703-711. 